\title{
Exploring Sentani Folktales of Papua as Media to Teach Local Language for Children
}

\author{
Wigati Yektiningtyas, Monika Gultom \\ Universitas Cenderawasih, Papua, Indonesia
}

\begin{abstract}
Sentani language in Papua Province is one of the world's many languages that almost extinct. It is also rich with folktales that were regularly passed down in the past from parents/grandparents to children/grandchildren with the purpose of transferring knowledge and moral values. However, only people who live in remote islands of Lake Sentani can speak the language actively while the children use it passively. Accordingly, preservation, especially for children, is deemed necessary to avoid the language from extinction. Recently, the elders in the remote areas told the tales to children irregularly in Indonesian language. The fact that the children like to listen to the tales encouraged the researcher to initiate a study on using folktales as media to teach Sentani language. This is the focus of this study and in particular, the rewriting of the folktales in simple language to be used as materials to teach Sentani language to children. Adopting socio-cultural and ethnolinguistic approaches in the fieldwork conducted from 2016 to 2018 in Jayapura, the study shows two findings. First, children do not speak the language because: (1) Parents do not speak and teach the language at home; (2) They feel that Sentani language is less prestigious than other languages; and (3) They face difficulties in pronunciation, sentence structure, tenses, adposition, and counting system. Second, the folktales help children in learning Sentani language with fun. These findings provide a social, psychological, linguistic, and pedagogical analysis of the preservation of almost extinct languages in a multilingual society.
\end{abstract}

Keywords: Sentani language, preservation, folktales

\section{Introduction}

Papua and Papua Barat Provinces in Tanah Papua are the only provinces in Indonesia that are very rich with local languages, spreading in the highland and coastal areas with various dialects. According to Balai Bahasa (Institution of Language) (2017), there are about 384 local languages in Tanah Papua (Papua and West Papua Provinces). Unfortunately, some of those local languages are labelled with "endangered", "dying”, and "loss" language. Sentani language is one of them that is labelled with "endangered" due to the fact that most people, especially young generation cannot speak the language anymore. Sentani people live in the edges and 19 islands of Sentani Lake in Jayapura as the capital of Papua province. Compared to other people who live in the highland and small towns, Sentani people experience contact with people from different parts of Tanah Papua and other places in Indonesia who came to Jayapura in recent 30 years due to the relatively easy and

Wigati Yektiningtyas, Dr., associate professor, Language Teaching and Arts Department, Faculty of Teacher Training and Education, Universitas Cenderawasih, Papua, Indonesia.

Monika Gultom, Dr., lecturer, Faculty of Teacher Training and Education, Universitas Cenderawasih, Papua, Indonesia. 
routine transportation to and from Jayapura. To maintain good communication with them, Sentani people tend to use Indonesian and Papuan Malay. Ironically, they also use Indonesian and Papuan Malay in their family.

The observation conducted in 2016-2017 proved that people who live in town or near the town cannot speak Sentani language. Only those people who live in the islands in Lake Sentani can speak the language actively, while some children cannot speak the language and some understand the language passively. This serious phenomenon cannot be ignored, and therefore, this fieldwork becomes an initiative that needs to be taken to save the language from extinction and save the children from losing their identity.

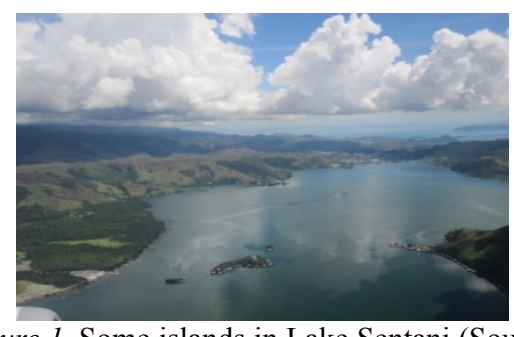

Figure 1. Some islands in Lake Sentani (Source: wigati yektiningtyas, 2015).

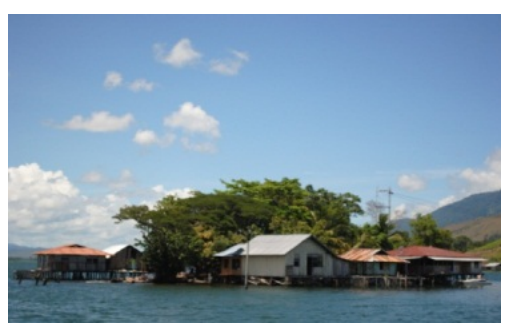

Figure 2. Houses of in the island in Lake Sentani (Source: wigati yektiningtyas, 2017).

Since language expresses culture (Palmer, 1996), not all words in Sentani language can be directly or homologically translated into other languages. In ehabla (Sentani oral poems), for example, some poems are opened with expression "Igwa yo, Huba yo". Literally, igwa and huba are synonymous which mean "prosperous" and yo means "village". Igwa and huba are actually archaic words and only used in literary works. According to John Ibo (76 years, informant), those words are imaginary ones to describe the idealization of Sentani people about a harmonious life. For old Sentani people, harmonious life was related to Sentani myth on three relations, namely, people to gods (creator), people to people, and people to nature. Those relations should be in a perfect condition and mutually connected to each other. Violence against them results in bad consequences, like sickness or death (pelo) (Revassy, 1989; Yektiningtyas \& Modouw, 2016). Prosperity to Sentani people deals with physical, emotional, spiritual, and social existence. Various terminologies in Sentani language are related to philosophy, mythology, and socio-culture that make one-to-one word translation cannot be done. Those above examples show that even a Sentani word loss leads to the loss of the whole life of the people: not only losing the words but also losing various aspects of socio-cultural life. To avoid those losses, preserving Sentani language by teaching it, especially for those young generations as the future generation of the Sentani society is urgently needed (Yektiningtyas \& Modouw, 2016).

In the past, Sentani people had various folktales that were orally passed down from one generation to another generation. Now, these folktales are not recognized by most people of Sentani. Only limited grandparents/parents in remote islands of Lake Sentani irregularly tell their grandchildren/children these folktales in Indonesian language. Some ondofolos (tribal chief) of Sentani: Enos Deda (Ayapo, 70 years), Moses Ohee (Kampung Harapan, 65 years), Ramses Ohee (Waena, 82 years), Mesak Kabey (Ifale, 60 years), D. Awoitauw (Puai, 66 years) explained that in the past, folktales were passed down to children in Sentani language for various purposes. Empirical experience proved that children were happy to listen to the tales that they called them as "stories about their life". They even told the tales to their friends. The ondofolos' explanation and children's happiness in listening to the folktales were combination of inspiration and encouragement to do this study on preserving Sentani language for children by using folktales. This idea is also 
related to Lazar's theory on literature and language teaching (2002) that highlighted the significance of using literature in teaching language, i.e., (1) motivating materials; (2) access to cultural background; (3) encouraging language acquisition; (4) expanding students' language awareness; (5) developing students' interpretative abilities; and (6) educating the whole person. Children's motivation and enthusiasm in listening to folktales can be used as stepping stones that lead them to learn more about their local language and proudly practice it.

Without preservation, Sentani language will slowly and surely be extinct seeing the fact that Sentani people tend to use Indonesian language and Papuan Malay to exchange communication with their interlocutors as the result of becoming part of the heterogenous society. Sentani children are prioritized in this study since they are the early generation of Sentani people who will preserve the whole life of Sentani socio-cultural heritages. This writing aims exploring two important problems related to preservation of Sentani language and revitalization of the folktales telling. They include: (1) Why Sentani children do not speak Sentani language? and (2) How to teach Sentani language to children by using folktales? The result of the study would be able to contribute positively to education sector, especially in relating to Sentani language teaching and folktales revitalization. Socio-politically, the study also gives input to stakeholders (tribal chiefs, society leaders, and local government) in making policy dealing with preservation of Sentani Language and socio-cultural heritages.

\section{Method}

This is a qualitative research that adopts ethnolinguistic and socio-cultural approaches. The primary data were the folktales gathered from the informants: tribal chiefs (ondofolo/khote/akona) and the elderly people. They were holistically supported by a series of observation, interviews, recordings, and long-participation of the researcher as a wife of a Sentani tribal chief as well. The secondary data were obtained from the written documents of previous researches and notes on culture, language, folklore, and folklife of the Sentani people. The selected folktales were then rewritten in children friendly language-considering language that is easy for children to follow. Since the folktales were told in Indonesian, the tales were then translated into Sentani language. Finally, focus group discussion was conducted with tribal chiefs, representative parents and teachers, and Sentani linguists to consider the validity and representation of the tales' essence and language.

The research was conducted in the areas of Sentani, Jayapura, including both the remote islands in Lake Sentani as well as the lake beach. Sentani area is bordered with Mount Cyclops or Dobonsolo (North), Nimboran District (South), Kemtuk District (East), and Arso District (West). The population lives in the $25.5 \mathrm{~km}^{2}$ wide of Lake Sentani beach and in remote islands in the lake. The population spreads in three major areas, namely, the East Sentani, the Central Sentani, and the West Sentani. They speak in three different dialects based on the areas they live: Eastern, Central, and Western Sentani dialects. However, such different dialects were not taken into account in this study since the different linguistic structures and vocabularies do not substantially change the meaning significantly. For example, the speakers may use different vocabularies in their encounters but they still understand each other.

Pedagogically, some simple examples of various aspects of language revealed in folktales have been chosen and designed and synergistically used as media to teach Sentani language for children. These teaching materials were then tried out in Asei Island (East Sentani) with children from Early Childhood Education, Kindergarten, and Primary School in 2017 and in Sentani Customary School in Hobong (Central Sentani) in 2018 to get feedback from children of 6-14 years old as the learners, instructors, parents, and tribal chiefs. Sentani Cutomary School was initiated in early of 2017 to teach Sentani culture, including Sentani language to children. The 
teaching learning process was helped and monitored by some fluent Sentani speakers. They are Corry Ohee (60 years), Martinus Ohee (57 years), Sarah Monim (45 years), and Sam Suebu (56 years).

This writing is a part of a big research conducted by the researcher in 2016-now. The research which was financially supported by the Ministry of Research, Technology and Higher Education of Indonesia entitled "Preservation of Sentani language for children by using Sentani folktales in Jayapura regency, Papua" (Yektiningtyas \& Gultom, 2017). A part of this writing, namely "The difficulties of Sentani children in learning their local language" has been presented in an International Conference on Local Languages (ICLL) in Udayana University, Denpasar on February 23, 2018 (Yektiningtyas, 2018).

\section{Discussion}

\section{Why Sentani Children do not Speak Sentani Language?}

Before teaching Sentani language for children using Sentani folktale, it is important to know the background why Sentani children do not speak their local language. After knowing the reasons, it is easier to prepare various strategies and teaching materials to help them. Through long observation, even long before doing the research in 2016, supported with interviews with tribal chiefs (ondofolo/khote), parents, and children, there are some social, psychological, and technical reasons why children do not speak Sentani language. They include: (1) Parents do not speak the language at home; (2) Children feel that Sentani language is not prestigious; and (3) They have difficulties in learning pronunciation, subject-object-predicate sentence structure (SOP/V), tenses, adposition, and counting system.

Socially, the biggest reason why Sentani children do not speak their local language is because their parents do not speak it at home. In recent 30 years, it is hard to hear Sentani parents speak Sentani language to their children. Naturally, no matter how complicated a language is, if it is spoken by the parents every day and it is taught to their children, the children will imitate and they can speak it. This was also supported by a khote in Asei Island and an ondofolo in Waena that most parents tend to speak in Indonesian and Papuan Malay to their children. From the interview with the parents and the tribal chiefs, it is found that parents tend to speak Indonesian and Papuan Malay due to two main reasons. Firstly, it is due to the ethnically mixed marriages. There are some mixed marriages in Sentani. If the father and the mother in a family come from different ethnic groups, the family usually eclectically will let the children speak Indonesian and/or Papuan Malay which is used as lingua franca in the society. Hermina Modouw (37 years), a Sentani woman, said that she could not force her children to speak Sentani since her husband is from Sorong. She thought that she had to respect her husband and his big family. Similarly, Terida Ongge (52 years), a good Sentani speaker, decided not to teach her children the language since her husband is a Bataknesse. Secondly, Sentani people in town live in a multilingual and multicultural society. Thus, even though both the father and the mother are from Sentani and they can speak the language, they do not teach the children this local language. They chose to teach them Indonesian language and/or Papuan Malay since they want their children to interact with other people outside their family. Thirdly, Sentani language is not used at school either as language of instruction or as language of written materials. Bani (45 years) and his wife, a Sentani couple, realizing that Indonesian is the only language used at school, they, no matter how much they want to teach the local language, finally decided to teach Indonesian to their children, so they can follow the teaching materials and can interact well with teachers and friends. Interestingly, at home, both of them speak Indonesian and Papuan Malay as their daily communication tools with their children. 
In the study, it is also found that psychologically, the children do not speak Sentani language because they thought the language is not prestigious compared to other languages, i.e., Indonesian and English. This ideological information comes from some teenagers after a series of interviews. Rere (13 years), Beno (12 years), and John (12 years) expressed their reasons why they do not speak Sentani language. In their views, Sentani language is less prestigious than other languages. If they speak it, they are afraid that their friends will despise them. They do not want to be seen as stupid, less modern, and left behind. Yakomina (13 years) said that she is not confident in speaking Sentani language since she wanted to be valued as "a modern girl" and "a smart girl". Speaking Indonesian and English helps her to be considered equal with other friends.

Besides, those social and psychological obstacles, technically Sentani children who are accustomed to Indonesian face difficulties in learning their local language, i.e., pronunciation, subject-object-predicate sentence structure (SOP/V), tenses, adposition, and counting system.

Hartzler (1992) in her study on Sentani phonology found that Sentani has seven vowels and variants, namely, vowel/i/ with two variants [i] and [I], vowel/e/ with two variants [ $\varepsilon]$ and [e], vowel/æ/,vowel/a/, vowel $/ \mathrm{o} /$, vowel /u/ with two variants [u] and [U], and vowel/o/. For those children who are accustomed to Indonesian pronunciation, it is sometimes hard to pronounce those vowels and the variants. For example, they cannot distinguish [i] in $i$ (fire) from [I] in igwa [Igwa] (name of imaginary village). They cannot distinguish [ $\varepsilon$ ] in $m e$ $[\mathrm{m} \varepsilon]$ (hand) from [e] in mei [məI] (come on). They cannot distinguish [æ] in maengge [mænggə] (girl) from [ $\varepsilon]$ in naugwe [naugwe] (do not know). They cannot distinguish [u] in $u$ (finish) from [U] in ugwa [Ugwa] (body). The distinction is important since mispronunciation will result in misunderstanding.

Sentani has 10 consonants, namely, consonant /p/ with three variants [ph], [b], and [B], cononant /t/ with

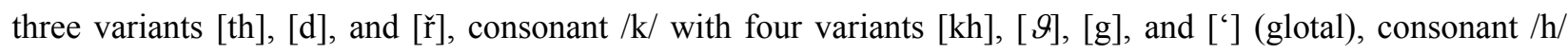
with two variants $[\mathrm{s}]$ and $[\mathrm{h}]$, consonant /f/, consonant /n/ with four variants $[\mathrm{y}]$, [yw], [ñ], and [n], consonant $/ \mathrm{m} /$, consonant $/ \mathrm{l} /$, consonant $/ \mathrm{y} /$ with two variants [dz] and $[\mathrm{y}]$, and consonant $/ \mathrm{w} /$. Those different consonants from Indonesian make them hard to pronounce the word oidzo (chicken) since in Indonesian there is no consonant $/ \mathrm{dz} /$. There are only consonant $/ \mathrm{d} /$ and $/ \mathrm{z} /$. It is also hard to pronounce yokhu [yo $\mathrm{u}$ ] (dog), since in Indonesian, there is no $/ \vartheta /$ sound. There are only $/ \mathrm{k} /, \mathrm{h} / \mathrm{h}$, and $/ \mathrm{kh} /$.

Different from Indonesian or English sentence structure that use subject-verb-object (SVO), Sentani language uses subject-object-verb (SOV) sentence structure. This is also one of the difficulties in learning Sentani language. For example, in English sentence, like "I (S) eat (V) banana (O)" is translated into Sentani language as "reyae (S) emfeu (O) anale (V)". Similarly, the sentence "She/he (S) eats (V) sweet potato (O)" is translated into Sentani language as "neyae $(\mathrm{S})$ ninggei $(\mathrm{O})$ anayae $(\mathrm{V})$ ". Likewise, "You $(\mathrm{S})$ are eating $(\mathrm{V})$ sago $(\mathrm{O})$ " is translated as "weyae $(\mathrm{S}) \mathrm{fi}(\mathrm{O})$ ne aneyae $(\mathrm{V})$ ".

Unlike Indonesian that does not have tenses, Sentani language applies some tenses. Sentani children face difficulties with the verb changes. Andreas Deda (personal discussion, April 2017), a Sentani linguist, showed that tenses are the biggest problem for Sentani children in communicating verbally and writtenly in the local language. Verbs change following time and verbs also change following the subjects. The examples below show those changes as emphasized in bold.

First Person Singular

\begin{tabular}{|l|l|}
\hline Sentani & English \\
\hline (1) Reyae kha anale & I eat fish \\
\hline (2) Reyae emfeu aneimiyale & I usually eat banana (as habitual) \\
\hline
\end{tabular}




\begin{tabular}{|l|l|}
\hline (3) Reyae kho anekokale & I ate coconut \\
\hline (4) Reyae ru ne anale & As usually, I am eating bread fruit \\
\hline (5) Reyae melasa anerekhonde & I will eat rice \\
\hline (6) Reyae ninggei anekokhale & I have eaten sweet potato \\
\hline (7) Reyae fam anewekhale & I had eaten taro \\
\hline
\end{tabular}

Second Person Singular

\begin{tabular}{|l|l|}
\hline Sentani & English \\
\hline (8) Weyae fi aneyae & You eat sago \\
\hline (9) Weyae melasa aneyeyae & You usually eat rice \\
\hline (10) Weyae kha kabham aneimiyeyae & As usually, you are eating big fish \\
\hline (11) Weyae kha khending anekokhae & You ate small fish \\
\hline (12) Weyae odzo ne aneyae & You are eating chicken \\
\hline (13) Weyae emfeu aneikonde (re) & You will eat banana \\
\hline (14) Weyae fi anekokhae & You have eaten sago \\
\hline (15) Weyae bia anewekhae & You had eaten freshwater shell \\
\hline
\end{tabular}

Third Person Singular

\begin{tabular}{|l|l|}
\hline Sentani & English \\
\hline (16) Neyae fi aneyae & She/he eats sago \\
\hline (17) Neyae melasa aneyeye-aneweye & She/he usually eats rice \\
\hline (18) Neyae emfeu aneimiyeye & As usually she/he is eating banana \\
\hline (19) Neyae kho anekokhe & She/he ate coconut \\
\hline (20) Neyae fam ne aneye & She/he is eating taro \\
\hline (21) Neyae ninggei anenggonde (re) & She/he will eat sweet potato \\
\hline (22) Neyae kha anekokhe & She/he has eaten fish \\
\hline (23) Neyae odzo aneiwekhe & She/he had eaten chicken \\
\hline
\end{tabular}

First Person Plural

\begin{tabular}{|l|l|}
\hline Sentani & English \\
\hline (24) Eyae kho anande & We eat coconut \\
\hline (25) Eyae fami aneyande-anewande & We usually eat taro \\
\hline (26) Eyae kha aneimiyande & As usually we eat fish \\
\hline (27) Eyae ru anande & We ate bread fruit \\
\hline$(28)$ Eyae fi nukhu ne anande & We are eating cold sago porridge \\
\hline (29) Eyae sinoleng anemakhonde (re) & We will eat baked sago \\
\hline (30) Eyae ninggei anekhokhande & We have eaten sweet potato \\
\hline (31) Eyae melasa anandekhe & We had eaten rice \\
\hline
\end{tabular}

Third Person Plural

\begin{tabular}{|l|l|}
\hline Sentani & English \\
\hline (32) Neyae bia anate & They eat freshwater shell \\
\hline (33) Neyae emfeu aneyate-anewate & They usually eat banana \\
\hline (34) Neyae kho anaimiyate & As usually they eat coconut \\
\hline (35) Neyae ninggei anaikokhate-anaikokhe & They ate sweet potato \\
\hline (36) Neyae melasa ne anate & They are eating rice \\
\hline (37) Neyae kha anaikonde (re) & They will eat fish \\
\hline (38) Neyae fi anaikokhe & They have eaten sago \\
\hline (39) Neyae ninggei anaiwekhe-anewekhate & They had eaten sweet potato \\
\hline
\end{tabular}


From the examples above, we notice that verbs change when the time and subjects change. For example, the subject and verb in Sentence 1 "reyae kha anale" (I eat fish), in Sentence 8 "weyae fi anayae" (You eat sago), in Sentence 24 "eyae kho anande (We eat coconut), in Sentence 32 "neyae bia anate" (They eat freshwater shell) and in Sentence 35 "neyae ninggei anaikokhe" (They ate sweet potato). The verb "anale" (to eat) with the subject "reyae" (I) changes to "anayae", "anande", "anate", and "anaikokhe" with the subjects weyae (you), eyae (we), and neyae (they) respectively. These complexities create problems for children in their efforts to learn their local language.

Instead of using prepositions, Sentani language uses postpositions. For example, "reyae kampus re" (I go to campus). The article re (to) is put after the complement, kampus (campus). Another example is "reyae imae $r a$ " (I am from home). The article $r a$ (from) is also put after the complement, imae (home).

For some people, especially Sentani children, counting system is too complicated. Sentani language uses five base numbers and it uses fingers, hands, toes, and body for the addition. Here are the examples: one = mbai, two $=b h e$, three $=$ name, four $=k e l i$, five $=$ mehembai $($ one hand); six $=$ me hinim mbai (one hand plus one finger), seven = me hinim bhe (one hand plus two fingers), eight = me hinim name (one hand plus three fingers), nine $=$ me hinim keli (one hand plus four fingers), ten = me bhe (two hands), eleven = me bhe oro khla-khla mbai jale (two hands plus one toe), twelve = me bhe oro khla-khla bhe jale (two hands plus two toes), thirteen = me bhe oro khla-khla name jale (two hands plus three toes), fourteen = me bhe oro khla-khla keli jale (two hands plus four toes), fifteen = me bhe orophe mbai jale (two hands plus one foot), sixteen = me bhe orophe mbai oro khla-khla mbai jale (two hands plus one foot plus one toe), seventeen = me bhe orophe mbai oro khla-khla phe jale (two hands plus one foot plus two toes), eighteen = me bhe orophe mbai oro khla-khla name jale (two hands plus one foot plus three toes), nineteen = me bhe orophe mbai oro khla-khla keli jale (two hands plus one foot plus four toes), and twenty = ugwa (one body).

From the background of why Sentani children do not speak their local language as explained above, it can be argued that socially and psychologically they need help, motivation, and encouragement from other figures like parents, tribal chiefs, teachers, and social leaders in order that they become aware of the significance and importance of learning their local language. Technically, the above identification of Sentani children's difficulties in learning their local language would encourage the researcher and other scholars in finding strategies and designing creative teaching materials to help them. Strategically, this study chose to utilize folktales, one of their cultural treasures as the media to learn Sentani language due to the fact that children like listening to folktales.

\section{Teaching Sentani Language to Children by Using Folktales}

This section discusses about teaching Sentani Language for children by using folktales. There are four folktales taken as the sources of the teaching materials: "Manggung re Bokiki re" (The Cassowary and the Sparrow), "Abepura Ahuba" (The Origin of Abepura's Name), "Ebi Kendeite" (Ebi and Kandei), and "Heram Yoni-yoni Puyakha Labure Megwate" (The Journey of Heram People to Sentani Lake). The teaching learning materials are designed in relation to the problem identification of Sentani children's obstacles in learning their local language, i.e., (1) pronunciation; (2) subject-object-verb sentence structure (SOV); (3) tenses; (4) adposition; and (5) counting system. As it was previously stated, the teaching-learning activities were practiced in Asei Island with a group of children from Early Childhood Education, Kindergarten and Primary Schools in 2017 and in Sentani Customary School, Hobong in 2018. 

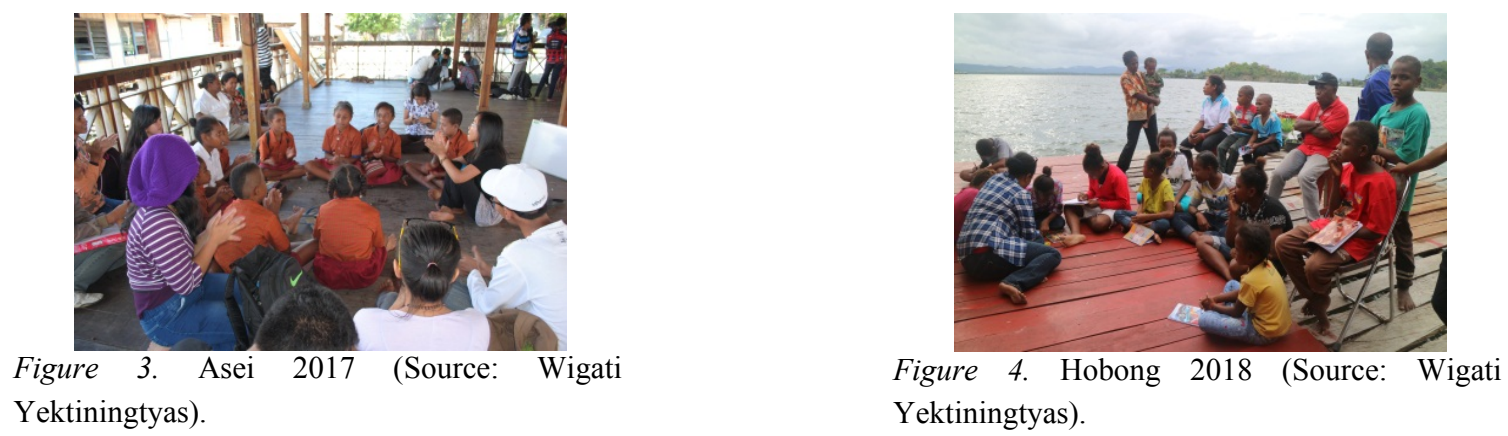

Since Sentani children are accustomed to Indonesian pronunciation, they have to be trained to be familiar with Sentani vowels and consonants, especially those that are not found in Indonesian. From the tales, the

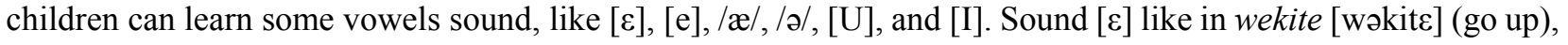

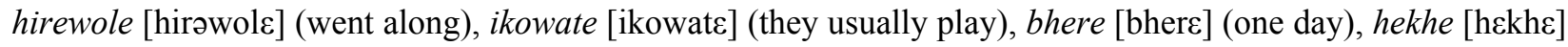
(garden), and fiye [fiys] (baked sago). Sound [e] like in anele [anəle] (eat), nyanyelere [nyanyeləre] (will give), and $r e$ [re] (to). Sound [æ] like in ayae [ayæ] (bird), uhilae-hilae [uhilæ-hilæ] (naughty), weungae [weungæ] (said), weyae [weyæ] (you), reyae [reyæ] (I), miyae [miyæ] (woman), and maengge [mænggə] (girl). Sound [ə] like in nekhende [nekhənde] (they will stay), fele-fele [fələ-fələ] (little), and khending [khənding] (little), khena [khəna] (heart), naume [naumə] (hot), weunge [weungə] (said), khelu [khəlu] (boy) and Ifale [ifalə] (name of a village). Sound [u] like in autaei [autæi] (advice/knowledge), manggung [manggung] (cassowary), and khelu [khəlu] (boy). Sound [U] like in ugwa [Ugwa] (body), uhilae-hilae [Uhilæ-hilæ] (naughty), yu [yU] (head), bhu [bhU] (water), humungga [hUmUngga] (mountain). Sound [I] like in khani [khanI] (earth), moni [monI] (hungry], bhuki [bhukI] (thirsty), mali [malI] (too much), hakhai (hakhaI] (dragon). Practice is needed to avoid misunderstanding and misinterpretation. For example, the word "hekhe" means "garden" if it is pronounced [hekhe] and means "yam" if it is pronounced [həkhə].

In Indonesian consonants, there is only [k] sound, while in Sentani there are [k] and [kh] sounds. Practice to distinguish these two sounds can be done by taking some words from the tales. For examples, sound [kh] like in akhla (jungle), khabani (big), khending (little), khani (earth), kha (fish), khayi (canoe), khoseyo (tribal chief), khelu fa (boy), khena (heart), hokholbe (both of them), nekhete (both live), Yakhohireuw (name of an ancient tribal chief), nagwakhe (his brother), and jokho (eye). While sound [k] like in ikowate (they usually play), bokiki (sparrow), nekewete (both lived), keija (a name of banana), ikele (angry), hilokokhae (he has swum), kemahe (ancestors), rokale (I have got), and ohaikokhae (they had passed).

After pronunciation, introducing children to vocabulary is the next step. From the tales, children do not only learn the meaning of a word but also its part of speech as figured out in the Table 1.

Table 1

Part of Speech in Sentani Language

\begin{tabular}{llll}
\hline No. & Words & Meaning & Part of speech \\
\hline 1 & Akhla & Jungle & Noun \\
2 & Ayae & Bird & Noun \\
3 & Bokiki & Sparrow & Noun \\
4 & Ere & To see & Verb \\
5 & Eyae & We & 3rd personal pronoun plural \\
\hline
\end{tabular}


(Table 1 continued)

\begin{tabular}{|c|c|c|c|}
\hline No. & Words & Meaning & Part of speech \\
\hline 6 & Fele-fele & Little & Adjective \\
\hline 7 & $F i$ & Sago & Noun \\
\hline 8 & Hakhai & Dragon & Noun \\
\hline 9 & Hekhe & Garden & Noun \\
\hline 10 & $H u$ & The sun & Noun \\
\hline 11 & Humungga & Mountain & Noun \\
\hline 12 & $I$ & Fire & Noun \\
\hline 13 & Ikele & Angry & Adjective \\
\hline 14 & Jokho & Eye & Noun \\
\hline 15 & Kha & Fish & Noun \\
\hline 16 & Khabham & Big & Adjective \\
\hline 17 & Khani & Earth & Noun \\
\hline 18 & Khayi & Canoe & Noun \\
\hline 19 & Keija & A kind of banana & Noun \\
\hline 20 & Khending & Little & Adjective \\
\hline 21 & Khelu & Son & Noun \\
\hline 22 & Khote & Tribal chief & Noun \\
\hline 23 & Lekei & Strong & Adjective \\
\hline 24 & Mali & Too much & Adverb \\
\hline 25 & Maengge & Girl & Noun \\
\hline 26 & Manggung & Cassowary & Noun \\
\hline 27 & Mbai & One & Numeral \\
\hline 28 & Miyae & Woman & Noun \\
\hline 29 & Moni & Hungry & Adjective \\
\hline 30 & Neyae & $\mathrm{He} / \mathrm{she}$ & 3 rd personal pronoun \\
\hline 31 & Onomi & Bless & Noun \\
\hline 32 & Oro & Leg & Noun \\
\hline 33 & Phuki & Thirsty & Adjective \\
\hline 34 & Reyae & I & 1st personal pronoun \\
\hline 35 & Ro & Man & Noun \\
\hline 36 & Rojando & Gentleman & Noun \\
\hline 37 & $U$ & Nothing/finish & Verb \\
\hline 38 & Ugwa & Body & Noun \\
\hline 39 & Uhilae-hilae & Naughty & Adjective \\
\hline 40 & Wali & Life & Noun \\
\hline 41 & Weunge & Said & Past verb \\
\hline 42 & Weyae & You & 3rd personal pronoun \\
\hline 43 & Yo & Village & Noun \\
\hline 44 & Yoho & Villagers & Noun \\
\hline
\end{tabular}

Those vocabularies are also good media for pronunciation and spelling practice. The classroom activities like games and songs are good practices to help the children in distinguishing sounds and memorizing the meaning of the words. For example, games on vocabularies, like guessing pictures, playing scrabbles, and spelling bee can be infused to strengthen their words acquisition. Similarly, song created from the tale like below can also be used for the similar purpose. 
Bokiki Fele-fele (Notation from Kidung Jemaat 385)

Little Sparrow

do $=\mathrm{D}$

D A

| $5535 \mid 432$.|

Bo kikifele-fele

O dear little sparrow

D

| $4426|5.3$.

Itaei foitaei nekai

You know how God loves you

$\mathrm{G}$

| $553 \mathrm{i}|7.7$.

Reyae foi moi sele

And I know about me

D A D

| 5342 |2.1.|

Ataei khabam kena

Mighty God loves me more

Understanding the part of speech helps the children in creating simple sentences. So, after having enough drills with vocabulary and teaching part of speech they belong to, the learners can be introduced to simple sentence structure of Sentani language. Since they are already accustomed to subject-verb-object structure, learning subject-object-verb structure of Sentani language needs special efforts. There are some examples of sentences in the folktales that can be taught to children as follows.

Table 2

Samples of Sentences from the Folktales

\begin{tabular}{lll}
\hline No. & Sentani & English \\
\hline 1 & $\begin{array}{l}\text { Bokiki (the sparrow/subject) manggung na jokho (the } \\
\text { cassowary's eye/object) femmae (pecked/verb) }\end{array}$ & $\begin{array}{l}\text { The sparrow (subject) pecked (verb) the cassowary's eye } \\
\text { (object) }\end{array}$ \\
$\begin{array}{l}\text { A nembanye elaikokhae (a group of birds/subject) } \\
\text { Manggung re (to the cassowary/object) hambungbate } \\
\text { (necklace/object) nyanyelere (gave) }\end{array}$ & $\begin{array}{l}\text { A group of birds (subject) gave (verb) the cassowary } \\
\text { (object) a magic necklace (object) }\end{array}$ \\
$\begin{array}{l}\text { Ya mbai (one day/complement of time), hokholbae } \\
\text { (they/subject) hekhe (garden/object) mokhonetere elete } \\
\text { (made/verb) }\end{array}$ & $\begin{array}{l}\text { One day (complement of time) they (subject) made (verb) a } \\
\text { garden (object) }\end{array}$ \\
5 & $\begin{array}{l}\text { Na (we/subject) emfeu (banana/object) anete (burnt/verb) } \\
\text { Kandei (subject) Ebi na jokhora (Ebi's eye/object) } \\
\text { khoubonogokhae (stabbed/verb) }\end{array}$ & They (subject) burnt (verb) bananas (object) \\
\hline
\end{tabular}

From those sentence examples, learners especially those from Primary Schools can be given more drills through other practices like translating Indonesian sentences into Sentani language or vice versa or creating their own Sentani sentences based on the given words. They can also learn how to create sentences by having different subjects. Empirically, this kind of activity brought lots of fun for the children since they wrote various sentences and made lots of mistakes as well. The class was busy with questions and discussions. For Primary 
School learners, limited tenses (present and past tense) can also be slowly introduced. From the tales, they can follow the examples as follows.

Table 3

Present and Past Tense in Sentani Language

\begin{tabular}{|c|c|c|}
\hline No. & Present tense & Past tense \\
\hline 1 & $\begin{array}{l}\text { Manggung mbai akhla nolo ne nekheye (There is a } \\
\text { cassowary in the jungle). }\end{array}$ & $\begin{array}{l}\text { Manggung mbai bure akhla nolo ne nekhewoye (There was } \\
\text { a cassowary in the jungle). }\end{array}$ \\
\hline 2 & $\begin{array}{l}\text { Nau khabam sele na fiye mehila-hila hele khoye (He is big } \\
\text { and naughty). }\end{array}$ & $\begin{array}{l}\text { Nau khabam sele na fiye mehila-hila khowoye (He was big } \\
\text { and naughty). }\end{array}$ \\
\hline 3 & $\begin{array}{l}\text { Aye hamang yaroye ehakhaibiyoye eye (He carries their } \\
\text { food away). }\end{array}$ & $\begin{array}{l}\text { Aye hamang yaroweye ehakhaibiyoye ewoye (He carried } \\
\text { their food away). }\end{array}$ \\
\hline 4 & $\begin{array}{l}\text { Aye nare ahung kholonainyele itei autei inyeinyelere (They } \\
\text { want to give him a lesson). }\end{array}$ & $\begin{array}{l}\text { Aye nare ahung kholonainyewendere itei autei } \\
\text { enainyewende (They wanted to give him a lesson). }\end{array}$ \\
\hline 5 & $\begin{array}{l}\text { Na horno ne nohei bulu ikainyele (They give him a magic } \\
\text { necklace). }\end{array}$ & $\begin{array}{l}\text { Na horno ne nohei bulu wokhainyele (They gave him a } \\
\text { magic necklace). }\end{array}$ \\
\hline
\end{tabular}

From those simple examples, the learners can learn the tenses marker i.e., from nekheye (present to be/is) to nekhewoye (past to be/was), khoye (present to be/is) to khowoye, yaroye ... eye (to collect) to yaroweye ... ewoye (collected), inyeinyelere (want) to enainyewende (wanted), and from ikainyele (to give) to wokhainyele (gave). The study found that children were frustrated with those verb changes. Slowly drills are recommended.

Sentani language uses postposition, instead of preposition. From the tales, the learners can learn some postposition such $n e$ (at, in), re (to), ra (from). i.e., akhla ne (in the jungle), akhla ra (from the jungle), bokiki re (to the sparrow), manggung re (for the cassowary). The learners can also practice other expressions like "from home" (imae ra), "from the garden" (hekhe ra), "to school" (sekolah re), "at home" (imae na), "for the mother" (ana re). They are encouraged to practice the postposition in sentences, i.e., "I am from home" (reyae imae ra), "I go to the garden" (reyae hekhe re), "He is in the jungle" (neyae akhlane), "The girl is at home" (maengge imae na), etc.

Counting system is complicated for the learners. Sentani language uses fingers, hands, toes, foot, and body for counting. From the tales, there is a word mbai (a/one) in "manggung mbai akhla ne nekhende" (There was a cassowary in the jungle) or "ya mbai hokholbae heke mokhonetere elete" (One day, they wanted to make a garden). It is true that there is only a number, namely, mbai (one) mentioned in the tales but the teacher can develop the teaching by giving the principle of counting in Sentani language and providing more practices. For example, a hand (mehembai) for "five", a hand plus one finger (me hinim mbai) for "six", two hands (me bhe) for ten, two hands plus one toe for eleven (me bhe oro khla-khla mbai jale), and a body (ugwa) for twenty. By having practices on this counting system the students are also helped to learn the vocabularies of human body parts and how they are pronounced.

The uniqueness of using folktales as media of teaching Sentani language lies in the fact that folktales can also be used as media of character building. Values of hardwork, communication, togetherness, cooperation, respect, and love are embedded in the tales. From "The Cassowary and the Sparrow", they can learn that being small does not mean that one is weak and fragile. From "Ebi and Kandei", they can learn that friendship is beyond food. From "Heram yoni-yoni", they can learn about the importance of cooperation, bravery, and strategy in life. From "The Origin of Abepura", children can learn that family affair is above all. It is important to provide children with social values through folktales as media of character building and strategies in facing life. 


\section{Conclusion}

Discussing about Sentani language and folktales is like two sides of the same knife: Both of them are important but both of them are left behind by the people. Teaching Sentani language using folktales means preserving the language and the folktales at once. Indeed, Sentani language is one of the local languages in Tanah Papua that is labelled as "endangered" language due to the fact that only few people can speak it and most children do not speak it anymore. However, preservation has been done through a pedagogical means as the first and important answer in order that the language will not be extinct and the children do not lose their identity.

The study found that children do not speak the language because parents do not speak and teach the language at home, they felt that Sentani language is less prestigious than other languages, and they face difficulties in learning their local language, i.e., pronunciation, sentence structure SOV, tenses, adposition, and counting system. Since learning Sentani is not easy, an interesting and creative teaching initiative has already been taken and this still needs further development and improvement. Folktale, even though rarely told recently, is regarded as an interesting media seeing the fact that children like to listen to it after being tried out at some schools.

The study also found that folktales helped them in learning Sentani language with fun. They could learn pronunciation, vocabularies, making short sentence, and counting without burden. Songs and games that were used also helped them in understanding the language during the teaching-learning process. The socio-cultural values embedded in these folktales can be used as media of character building.

The study recommends the stakeholders (tribal chiefs and government) to motivate and encourage parents and the elders to speak Sentani at home, so the children are accustomed to listen and imitate to speak the language and change their mindset that Sentani language is invaluable heritage to preserve.

\section{References}

Abrams, M. H. (1979). The mirror and the lamp: Romantic theory and the critical tradition. New York, N.Y.: Oxford University Press.

Badan Bahasa (Institution of Language) (2017). Bahasa dan Peta Bahasa di Indonesia (Languages and Map of Languages in Indonesia). Jakarta: Badan Bahasa.

Danandjaja, J. (2007). Foklor Indonesia: Ilmu gosip, dongeng, dan lain-lain (Indonesian Folklore: Gossip Science, Fairytales, and Others). Jakarta: PT Temprint.

Deda, Andreas. (2015). Kamus bilingual: Sentani, Indonesia, inggris (Biilingual Dictionary: Sentani, Indonesia, English). Jayapura: ARKA.

Dorson, R. M. (1976). Folklore and fakelore: Essays toward a discipline of folk studies. Harvard: Harvard University Press.

Dundes, A. (Ed.). (1984). Sacred narrative: Readings in the theory of myth. Berkeley: University of California Press.

Dundes, A. (1980). Interpreting folklore. Bloomington and London: Indiana University Press.

Dorson, R. M. (Ed.). (1972). Folklore and folklife. Chicago: The University of Chicago Press.

Fernandez, I. Y. (2008). Kearifan lokal komunitas etnik: Kontribusinya dalam kebangkitan Bangsa melalui Bahasa dan Budaya (Local Wisdom of Ethnic Community: Its Contribution in the Rise of Nation through Language and Culture). Samarinda: Balai Bahasa Samarinda.

Harzler, M. (1992). A brief phonology of the Sentani. Jayapura: Percetakan Universitas Cenderawasih.

Kamma, F. C. (1975). Religious text of the oral tradition form Western New Guinea (Irian Jaya)—Part A: The origin and sources of life. Leiden: E.J. Brill.

Lazar, G. (2002). Literature and language teaching. Cambridge: Cambridge University Press.

Omrod, J. E. (2009). Psikologi pendidikan membantu siswa tumbuh dan berkembang (Psychology of Education in Helping Students to Grow and Developed). Jakarta: Erlangga. 
Palmer, G. B. (1996). Towards a theory of cultural linguistics. Austin: University of Texas Press.

Revassy, L. (1989). "Kepemimpinan Tradisional di Pedesaan Irian Jaya: Studi Kasus di Desa Ajau Sentani, Jayapura”. Jakarta: Universitas Indonesia (Tesis S2). 'Traditional Leadership in Irian Jaya Villages: A Case Study in Ajau Village, Sentani, Jayapura. Jakarta: Universitas Indonesia (a Thesis).

Santrok, J. W. (2009). Educational psychology. New York, N.Y.: McGraw Hill Int.

Yektiningtyas-Modouw, W., \& Karna, S. R. W. (2013). Using folktales to strengthen literacy in Papua. Australian and International Journal of Rural Education, 23(3), 94-107.

Yektiningtyas-Modouw, W., Jakarimilena, R. F. N. (2009). Sentani folklore: Revealing social wisdom of Sentani people (A research report supposted by the Ministry of Education and Culture of Republic of Indonesia).

Yektiningtyas, W., \& Modouw, J. (2016). Infusing culture in English learning: An attempt to preserve cultural heritages in Jayapura municipality, Papua. Retrieved from http://www.e-journal.usd.ac.id/index.php/LLT

Yektiningtyas, W., \& Gultom, M. (2017). Preserving Sentani language for children by using folktales (A research report supported by the Ministry of Resseach, Techonlogy and Higher Education of Republic of Indonesia).

Yektiningtyas, W. (2018). Identifying Sentani children's difficulties in learning their language. Proceeding of International Confrence on Local Language, 22nd-23rd of February, Universitas Udayana, Bali. 